\title{
Stream Water Quality in Coal Mined Areas of the Lower Cheat River Basin, West Virginia and Pennsylvania, During Low-Flow Conditions, July 1997
}

by Donald R. Williams, Mary E. Clark, and Juliane B. Brown

\section{MAJOR WATER-QUALITY ISSUES}

In 1995, American Rivers, a national river conservation organization, placed the Cheat River at number 8 on its list of the 10 "most endangered" rivers in North America because of the severe acid mine drainage $(A M D)$ problems in the lower part of the basin.

In 1996, the West Virginia Department of Environmental Protection (WVDEP) developed a "Watershed Approach Protocol" for monitoring, evaluating, and proposing remediation of AMD throughout the lower Cheat River Basin.

In 1996, the Cheat River was selected as a major integrator site for the Allegheny-Monongahela River Basin (ALMN) study unit as part of the U.S. Geological Survey's (USGS) National Water Quality Assessment (NAWQA) Program. The NAWQA Program was designed for the protection and enhancement of the quality of the Nation's groundwater and surface-water resources.

\section{INTRODUCTION}

The Cheat River Basin (fig. 1) is in the Allegheny Plateau and Allegheny Mountain Sections of the Appalachian Plateau Physiographic Province (Fenneman, 1946) and is

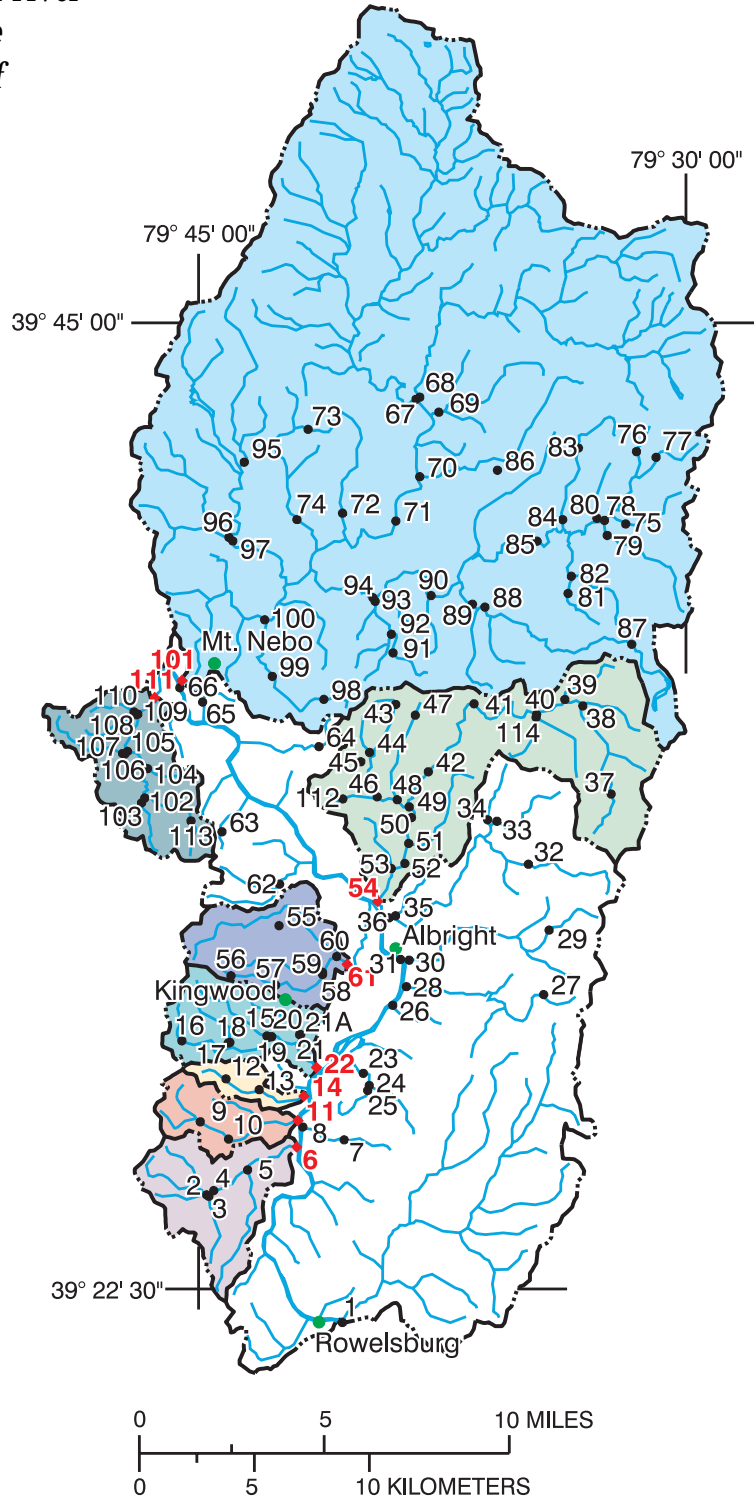

Figure 1. Location of the Lower Cheat River Basin, major tributary stream basins, and sampling sites. (Site numbers, site names, and drainage areas are given in table 1.) 
almost entirely within the state of West Virginia. The Cheat River drains an area of 1,422 square miles in Randolph, Tucker, Preston, and Monongalia Counties in West Virginia and Fayette County in Pennsylvania. From its headwaters in Randolph County, W.Va., the Cheat River flows 157 miles north to the Pennsylvania state line, where it enters the Monongahela River. The Cheat River drainage comprises approximately 19 percent of the total Monongahela River Basin. The Cheat River and streams within the Cheat River Basin are characterized by steep gradients, rock channels, and high flow velocities that have created a thriving white-water rafting industry for the area. The headwaters of the Cheat River contain some of the most pristine and aesthetic streams in West Virginia. The attraction to the area, particularly the lower part of the Cheat River Basin (the lower 412 square miles of the basin), has been suppressed because of poor water quality. The economy of the Lower Cheat River Basin has been dominated by coal mining over many decades. As a result, many abandoned deep and surface mines discharge untreated acid mine drainage (AMD), which degrades water quality, into the Cheat River and many of its tributary streams. Approximately 60 regulated mine-related discharges (West Virginia Department of Environmental Protection, 1996) and 185 abandoned mine sites (U.S. Office of Surface Mining, 1998) discharge treated and untreated AMD into the Cheat River and its tributaries.

The West Virginia Department of Environmental Protection (WVDEP) Office of Abandoned Mine Lands and Reclamation (AML\&R) has recently completed several AMD reclamation projects throughout the Cheat River Basin that have collectively improved the mainstem water quality. The AML\&R office is currently involved in acquiring grant funds and designing treatment facilities for several additional AMD sites that adversely affect the Cheat River and its tributaries. To obtain the baseline water-quality information necessary to evaluate instream treatment and alternative methods for remediating AMD and its effects, the U.S. Geological Survey (USGS), in cooperation with the WVDEP, collected stream water samples at 111 sites throughout the Lower Cheat River Basin during low-flow conditions from July 16-18, 1997. The data also will provide information on stream water quality in areas affected by AMD and thus would point to priority areas of focus, such as the sources of the AMD. This report presents the results of analyses of the samples collected in July 1997 and describes a process for ranking of stream water-quality degradation as a guide to water-resource managers considering AMD remediation activities.

\section{MONITORING NETWORK AND SAMPLING CONDITIONS}

The WVDEP selected the sampling locations for the comprehensive monitoring network of the Lower Cheat River Basin (fig. 1). The monitoring network included 3 mainstem sites and 112 tributary sites scheduled to be sampled 3 times over a range of streamflow conditions that included high, medium, and low flow. Only 111 of the 115 sites were sampled during low flow because four of the sites (sites 5, 13, 73, and 75) had no flow. The monitoring network included the mainstem of the Cheat River at the town of Rowelsburg, W. Va. (site 1), downstream to the Cheat River at the Jenkintown bridge (site 66). The third mainstem site (site 31) was at the town of Albright, $\mathrm{W}$. Va., approximately midway between mainstem sites 1 and 66. The monitoring network also included 112 tributary sites. Eight major tributary sites included Pringle Run (site 6), Lick Run (site 11), Heather Run (site 14), Morgan Run (site 22), Greens Run (site 61), Muddy Creek (site 54), Big Sandy Creek (site 101), and Bull Run (site 111). The WVDEP had previously completed two sampling runs at all sites during medium flow and medium to high flow conditions in June and November 1996, respectively. The third sampling run during low flow from July 16-18, 1997, provided the necessary information to assess the existing water-quality conditions of the Lower Cheat River Basin for a wide range of streamflow conditions. The site number, site name, and drainage area for each of the 115 sites are listed in table 1 . The sampling sites within the eight major tributary streams listed above are color coded in all tables and figures throughout this report. All water-quality and streamflow data collected throughout the Lower Cheat River Basin from July 16-18, 1997, are published in the USGS Water-Data Report PA 97-3 (Coll and Siwicki, 1997).

During low-flow conditions, most streamflow is sustained by natural ground-water discharge or by groundwater discharge from mine drainage or by both. During low flow, dilution from surface runoff is at a minimum, and therefore concentrations of constituents from natural ground-water dissolution of the rocks or from mine discharges are at a maximum. Consequently, sampling during low flow can provide a "worst case" scenario of stream water quality. Prior to sampling on July 16-18, 1997, the last appreciable rainfall in the Cheat River Basin was on July 9, 1997, when 0.44 inch of rain fell in Preston County near Kingwood, W. Va. On July 10, 0.04 inch of rainfall was recorded for Preston County. From July 10 until after the low-flow sampling was completed on July 18,1997 , no rainfall was recorded.

\section{WATER QuALITY IN THE MAINSTEM}

The mainstem of the Cheat River was sampled at three locations. The downstream location was near Mt. Nebo, W. Va. (site 66), at the Jenkintown bridge, which is about 7.6 river miles above Cheat Lake. This site is considered the outflow site, and it is also a basic fixed integrator site for the Allegheny-Monongahela River Basin National Water Quality Assessment (ALMN-NAWQA) study unit. A NAWQA basic fixed integrator site represents water-quality conditions of streams in heterogeneous large basins that are commonly affected by 
Table 1. Site number, name, and drainage area for all sites in the monitoring network in the Lower Cheat River Basin [mi ${ }^{2}$, square miles; Cr, creek; Fk, Fork; Mth, mouth; No., number; nr, near; R., River; Rn, Run; Trib, Tributary; Unn, unnamed]

\begin{tabular}{|c|c|c|c|c|c|c|c|c|}
\hline $\begin{array}{c}\text { Site } \\
\text { number }\end{array}$ & Site name & $\begin{array}{c}\text { Drainage } \\
\text { area } \\
\left(\mathrm{mi}^{2}\right)\end{array}$ & $\begin{array}{c}\text { Site } \\
\text { number }\end{array}$ & Site name & $\begin{array}{c}\text { Drainage } \\
\text { area } \\
\left(\mathrm{mi}^{2}\right)\end{array}$ & $\begin{array}{c}\text { Site } \\
\text { number }\end{array}$ & Site name & $\begin{array}{c}\text { Drainage } \\
\text { area } \\
\left(\mathrm{mi}^{2}\right)\end{array}$ \\
\hline 11 & Cheat R. at Rowelsburg, W.Va. & 939 & 39 & Jump Rock Rn at Mth & 1.04 & 77 & Unn Trib. No. 3 of Cherry Rn & 1.00 \\
\hline 2 & Right Fk Pringle Rn at Mth & 3.67 & 40 & Unn Trib of Muddy Cr at Mth & 2.82 & & nr Headwaters & \\
\hline 3 & Left Fk Pringle Rn at Mth & 1.58 & 41 & Muddy $\mathrm{Cr}$ at Brandonville Turnpike & 15.1 & 78 & Cherry Rn at Mth & 5.81 \\
\hline 4 & Pringle $\mathrm{Rn}$ below Fks & 5.56 & 42 & Muddy $\mathrm{Cr}$ above Martin $\mathrm{Cr}$ & 18.5 & 79 & Mill Rn nr Mth & 4.64 \\
\hline${ }^{2} 5$ & Unn Trib No. 2 of Pringle Rn & 1.95 & 43 & Glade Rn nr Headwaters & .60 & 80 & Piney $\mathrm{Rn}$ at Mth & 1.55 \\
\hline${ }^{3} 6$ & Pringle Rn at Mth & 9.86 & 44 & Unn Trib No. 2 of Glade Rn at Mth & .73 & 81 & Elk Rn above Unn Trib & 1.13 \\
\hline 7 & Joes Rn above Unn Trib No. 1 & 1.09 & 45 & Unn Trib No. 1 of Glade Rn at Mth & .49 & 82 & Elk Rn nr Mth & 3.52 \\
\hline 8 & Joes Rn nr Mth & 2.44 & 46 & Glade Rn at Mth & 3.74 & 83 & Hog Rn nr Headwaters & 2.56 \\
\hline 9 & Lick Rn below Fks & 1.76 & 47 & Fickey Rn nr Headwaters & .25 & 84 & Hog Rn nr Mth & 3.93 \\
\hline 10 & Lick Rn above Unn Trib No. 1 & 2.78 & 48 & Fickey $R n$ at Mth & 1.47 & 85 & Little Sandy Cr below Hog Rn & 22.2 \\
\hline${ }^{3} 11$ & Lick Rn nr Mth & 4.89 & 49 & Martin $\mathrm{Cr}$ at Mth & 7.50 & 86 & Barnes $\mathrm{Rn}$ & 2.42 \\
\hline 12 & Heather Rn above Unn Trib No. 2 & .56 & 50 & Muddy $\mathrm{Cr}$ below Martin $\mathrm{Cr}$ & 19.7 & 87 & Beaver $\mathrm{Cr}$ nr Headwaters & 2.02 \\
\hline 213 & Unn Trib No. 1 of Heather Run & .50 & 51 & Crab Orchard $\mathrm{Cr}$ at Mth & 2.98 & 88 & Beaver $\mathrm{Cr}$ above Glade $\mathrm{Rn}$ & 9.48 \\
\hline${ }^{3} 14$ & Heather Rn at Mth & 2.21 & 52 & Unn Trib No. 2 of Muddy Cr & .26 & 89 & Beaver $\mathrm{Cr}$ nr Mth & 12.3 \\
\hline 15 & Morgan $\mathrm{Rn}$ above Church $\mathrm{Cr}$ & 1.92 & 53 & Sypolt Rn at Mth & 1.32 & 90 & Little Sandy $\mathrm{Cr}$ below Beaver $\mathrm{Cr}$ & 42.9 \\
\hline 16 & Church $\mathrm{Cr}$ nr Headwaters & .85 & ${ }^{3} 54$ & Muddy $\mathrm{Cr}$ at Mth & 33.8 & 91 & Webster Rn nr Headwaters & 1.15 \\
\hline 17 & Left Fk Unn Trib. of Church Cr. at Mth & .26 & 55 & Greens $\mathrm{Rn}$ above South Fork at & 3.90 & 92 & Unn Trib of Webster Rn & 1.54 \\
\hline 18 & Right Fk Unn Trib of Church Cr at Mth & .62 & & Pleasantdale, W.Va. & & 93 & Webster Rn at Mth & 4.05 \\
\hline 19 & Church $\mathrm{Cr}$ at Mth & 3.35 & 56 & South Fk Greens Rn nr Headwaters & .21 & 94 & Little Sandy Cr nr Mth & 51.3 \\
\hline 20 & Morgan $\mathrm{Rn}$ below Church $\mathrm{Cr}$ & 5.37 & 57 & South Fk Greens Rn above limestone fines & .72 & 95 & Laurel $\mathrm{Rn}$ above Patterson $\mathrm{Rn}$ & 5.82 \\
\hline 21 & Unn Trib No. 1 of Morgan Rn nr Mth & 1.72 & 58 & South Fk Greens Rn above Middle Fk & 1.97 & 96 & Little Laurel Rn at Mth & 6.68 \\
\hline $21 \mathrm{~A}$ & Unn Trib of Morgan Rn nr Kingwood, W.Va. & 1.50 & 59 & Middle Fk Greens Rn at Mth & 1.48 & 97 & Laurel Rn nr Mth & 20.5 \\
\hline${ }^{3} 22$ & Morgan Rn at Mth & 6.49 & 60 & Greens Rn below South and Middle Fks & 5.37 & 98 & Sovern $\mathrm{Rn}$ at Headwaters & 1.14 \\
\hline 23 & Buffalo Rn below Unn Trib No. 1 & 4.78 & ${ }^{3} 61$ & Greens $\mathrm{Rn}$ below South Fk & 9.27 & 99 & Sovern Rn at Hudson, W.Va. & 2.80 \\
\hline 24 & Buffalo Rn above Unn Trib No. 2 & 2.61 & 62 & Laurel $R n$ above Hogback Rn & 1.97 & 100 & Sovern $\mathrm{Rn}$ at Mth & 5.37 \\
\hline 25 & Unn Trib No. 2 of Buffalo Rn & 1.53 & 63 & Hacklebarney Rn nr Headwaters & .54 & ${ }^{3} 101$ & Big Sandy Cr at Mth & 208 \\
\hline 26 & Ashpole Rn at Mth & 1.66 & 64 & Conner Rn nr Headwaters & .54 & 102 & Right Fk Bull Rn at Mth & 1.39 \\
\hline 27 & Elsey Rn nr Headwaters & .88 & 65 & Gibson Rn nr Mth & .71 & 103 & Left Fk Bull Rn at Mth & 1.97 \\
\hline 28 & Elsey Rn at Mth & 6.23 & ${ }^{1} 66$ & Cheat R. above Big Sandy $\mathrm{Cr}$ & 1,131 & 104 & Unn Trib No. 2 at Mth & 1.06 \\
\hline 29 & Dority $\mathrm{Rn}$ at Mth & 1.74 & 67 & Big Sandy Cr above Little Sandy Cr & 54.4 & 105 & Bull Rn below Unn Trib No. 2 & 5.41 \\
\hline 30 & Daugherty $\mathrm{Rn}$ at Mth & 9.29 & 68 & Little Sandy Cr at Mth & 28.1 & 106 & Lick Rn at Mth & 1.24 \\
\hline${ }^{1} 31$ & Cheat R. at Albright, W.Va. & 1,048 & 69 & Unn Trib of Big Sandy Cr nr Clifton Mills, W.Va. & 5.82 & 107 & Mountain Rn at Mth & 1.38 \\
\hline 32 & Roaring $\mathrm{Cr}$ above Lick $\mathrm{Rn}$ & 3.04 & 70 & Glade $\mathrm{Rn}$ at Mth & 4.94 & 108 & Bull Rn above Middle $\mathrm{Rn}$ & 8.71 \\
\hline 33 & Lick Rn above Little Lick Rn & 2.46 & 71 & Big Sandy Cr at Bruceton Mills, W.Wa. & 99.2 & 109 & Middle Rn at Mth & .86 \\
\hline 34 & Little Lick Rn at Mth & 2.29 & 72 & Glade Rn nr Mth & 3.54 & 110 & Unn Trib No. 1 at Mth & .87 \\
\hline 35 & Unn Trib No. 1 of Roaring Cr at Mth & .98 & ${ }^{2} 73$ & Hazel Rn nr Headwaters & .82 & $3_{111}$ & Bull Rn at Mth & 11.0 \\
\hline 36 & Roaring $\mathrm{Cr}$ at Mth & 15.4 & 74 & Hazel Rn nr Mth & 5.34 & 112 & Martin $\mathrm{Cr}$ at Headwaters & .70 \\
\hline 37 & Muddy $\mathrm{Cr}$ nr Headwaters & 2.88 & ${ }^{2} 75$ & Little Sandy Cr above Cherry Run & 1.35 & 113 & Left Fk Bull Rn at Headwaters & 1.02 \\
\hline 38 & Muddy $\mathrm{Cr}$ above Sugarcamp $\mathrm{Rn}$ & 5.97 & 76 & Cherry Rn nr Headwaters & .88 & 114 & Unn Trib of Muddy $\mathrm{Cr}$ & 1.77 \\
\hline
\end{tabular}

complex combinations of land-use settings, point sources, and natural influences. Site 66 is downstream of six major tributary streams that include Greens Run (site 61), Muddy Creek (site 54), Morgan Run (site 22),

Heather Run (site 14), Lick Run (site 11), and Pringle Run (site 6). Big Sandy Creek (site 101) and Bull Run (site 111) flow into the Cheat River about 0.1 mile and 0.8 mile, respectively, downstream of site 66 and thus have no effect on the river water quality at site 66 . The mainstem also was sampled at the State Route 26 bridge in Albright, W. Va. (site 31), which is about 10.0 river miles upstream from site 66 and 0.5 mile downstream of the Albright Power Plant. Site 31 is downstream of Pringle Run (site 6), Lick Run (site 11), Heather Run (site 14), and Morgan Run (site 22). The mainstem sampling location furthest upstream was near Rowelsburg, W. Va. (site 1). Site 1 is upstream of the eight major tributary streams that significantly affect the water quality of the mainstem.

Results of analyses of water samples collected at the three mainstem sites and the eight major tributary sites from July 16-18, 1997, are summarized in table 2. The mainstem water quality became progressively degraded downstream from site 1 to outflow site 66 . Specific conductance increased from $110 \mu \mathrm{S} / \mathrm{cm}$ (microsiemens per centimeter at 25 degrees Celsius) to $220 \mu \mathrm{S} / \mathrm{cm}, \mathrm{pH}$ decreased from 7.7 to 6.2 , alkalinity decreased from $26 \mathrm{mg} / \mathrm{L}$ (milligrams per liter) to $4.5 \mathrm{mg} / \mathrm{L}$, sulfate concentrations increased from $19 \mathrm{mg} / \mathrm{L}$ to $81 \mathrm{mg} / \mathrm{L}$, and total manganese concentrations 
Table 2. Results of analyses of water samples collected from the three mainstem sites and the eight major tributary sites in the Lower Cheat River Basin, July 16-18, 1997

$\left[\mathrm{ft}^{3} / \mathrm{s}\right.$, cubic feet per second; $\mu \mathrm{S} / \mathrm{cm}$, microsiemens per centimeter at 25 degrees Celsius; $\mathrm{mg} / \mathrm{L}$, milligrams per liter; $\mu \mathrm{g} / \mathrm{L}$, micrograms per liter; <, less than; --, no data available]

\begin{tabular}{|c|c|c|c|c|c|c|c|c|c|}
\hline $\begin{array}{c}\text { Site } \\
\text { number }\end{array}$ & $\begin{array}{l}\text { Streamflow } \\
\left(\mathrm{ft}^{3} / \mathrm{s}\right)\end{array}$ & $\begin{array}{c}\text { Specific } \\
\text { conductance } \\
(\mu \mathrm{S} / \mathrm{cm})\end{array}$ & $\begin{array}{c}\mathrm{pH} \\
\text { (units) }\end{array}$ & $\begin{array}{c}\text { Acidity, } \\
\text { total heated } \\
\left(\mathrm{mg} / \mathrm{L} \text { as } \mathrm{CaCO}_{3}\right)\end{array}$ & $\begin{array}{c}\text { Alkalinity, total } \\
\left(\mathrm{mg} / \mathrm{L} \text { as } \mathrm{CaCO}_{3}\right)\end{array}$ & $\begin{array}{c}\text { Sulfate, } \\
\text { dissolved } \\
\text { (mg/L) }\end{array}$ & $\begin{array}{l}\text { Iron, total } \\
\quad(\mu \mathrm{g} / \mathrm{L})\end{array}$ & $\begin{array}{c}\text { Manganese, } \\
\text { total }(\mu \mathrm{g} / \mathrm{L})\end{array}$ & $\begin{array}{c}\text { Aluminum, } \\
\text { dissolved } \\
(\mu \mathrm{g} / \mathrm{L})\end{array}$ \\
\hline \multicolumn{10}{|c|}{ Mainstem Sites } \\
\hline 1 & 128 & 110 & 7.7 & 11 & 26 & 19 & 70 & 31 & 50 \\
\hline 31 & 151 & 167 & 7.0 & $<5$ & 14 & 46 & 110 & 67 & 140 \\
\hline 66 & 174 & 220 & 6.2 & $<5$ & 4.5 & 81 & 40 & 290 & 70 \\
\hline \multicolumn{10}{|c|}{ Major Tributary Sites } \\
\hline 6 & .97 & 827 & 3.4 & 105 & 1.7 & 370 & 980 & 2,700 & 12,000 \\
\hline 11 & 1.7 & 2,180 & 2.6 & 750 & 1.6 & 1,300 & 190,000 & 2,500 & 150,000 \\
\hline 14 & .65 & 1,070 & 3.0 & 185 & 1.9 & 430 & 6,700 & 1,800 & 21,000 \\
\hline 22 & 1.7 & 1,420 & 2.8 & 380 & 1.8 & 680 & 41,000 & 2,500 & 38,000 \\
\hline 54 & 11 & 1,690 & 3.2 & 199 & -- & 870 & 17,000 & 4,200 & 17,000 \\
\hline 61 & .90 & 1,490 & 2.8 & 332 & 1.8 & 710 & 34,000 & 3,200 & 26,000 \\
\hline 101 & 18 & 253 & 7.1 & 9.4 & 14 & 85 & 20 & 33 & 70 \\
\hline 111 & 4.7 & 1,090 & 3.2 & 154 & 1.9 & 530 & 3,400 & 1,700 & 15,000 \\
\hline
\end{tabular}

increased from $31 \mu \mathrm{g} / \mathrm{L}$ (micrograms per liter) to $290 \mu \mathrm{g} / \mathrm{L}$. Total iron and total aluminum increased from site 1 to site 31 and decreased from site 31 to site 66. These constituents are generally unstable in a changing $\mathrm{pH}$ environment and can precipitate out of solution and dissolve back into solution as the $\mathrm{pH}$ increases and decreases, respectively. The six AMD-affected tributaries flowing into the mainstem probably have the most significant effect on the mainstem water quality at site 31 and site 66. Although there was a progressive degradation in the water quality of the Lower Cheat River, overall, the water quality at mainstem site 66 was not highly degraded on the basis of the sample analyses. A pH of 6.2 , a specific conductance of $220 \mu \mathrm{S} / \mathrm{cm}$, an alkalinity concentration of $4.5 \mathrm{mg} / \mathrm{L}$, and an acidity concentration of less than $5 \mathrm{mg} / \mathrm{L}$ are water-quality conditions not indicative of severe AMD effects. Therefore, reclamation efforts throughout the Cheat River Basin appear to have greatly benefited the water-quality conditions in the Lower Cheat River. Extensive reclamation work was completed on eight sites in the Upper Cheat River Basin in Tucker County along the Blackwater River and its tributaries. These efforts included passively treating AMD by diverting a mine discharge through any combination of constructed wetlands, anoxic limestone drains, or successive alkalinity producing systems (SAPS), eliminating highwalls, regrading and revegetating coal refuse and mine spoil areas, and constructing a limestone drum treatment facility. Within Preston County, more than 60 AML\&R sites that adversely affect the water quality of the Cheat River have been identified. To date, the AML\&R office has completed 25 reclamation projects in Preston County within the Cheat River Basin, and efforts to acquire grant funds have begun and preliminary remediation designs are underway for several additional AMD sites that adversely affect the Cheat River and its tributaries (West Virginia Department of Environmental Protection, Office of Abandoned Mine Lands and Reclamation, written commun., 1998).

\section{WATER QUALITY IN THE MAJOR TRIBUTARIES}

Data from all major tributary sites except Big Sandy Creek (site 101) showed evidence of severe AMD effects. At those seven tributary sites, specific conductance ranged from 827 to $2,180 \mu \mathrm{S} / \mathrm{cm}$, $\mathrm{pH}$ values were all less than 3.5, acidities ranged from 105 to $750 \mathrm{mg} / \mathrm{L}$, sulfate concentrations ranged from 370 to $1,300 \mathrm{mg} / \mathrm{L}$, and concentrations of iron, manganese, and aluminum (total and dissolved) were all very high (table 2).

Discharges of acidity, sulfate, and manganese from the eight tributary sites and from the three mainstream sites are shown in figure 2 . Although the acidity discharges in the mainstem decreased from 3.8 ton/d (tons per day) at the upstream site 1 to less than 2 ton/d at mainstem site 31 and outflow site 66 , the cumulative acidity discharge from six tributary sites between the upstream and downstream mainstem sites was over 12 ton/d. Lick Run (site 11) and Muddy Creek (site 54) contributed 75 percent of the total tributary discharge of acidity; Lick Run contributed 3.4 ton/d (27 percent), and Muddy Creek contributed 5.9 ton/d (48 percent). Downstream of mainstem site 66, Big Sandy Creek (site 101) and Bull Run (site 111) contributed acidity discharges of 0.5 ton/d and 2.0 ton/d, respectively, to the mainstem.

Neutralization reactions in streams generally do not change sulfate concentrations. Similarly, manganese oxidation reactions and precipitation are strongly affected by $\mathrm{pH}$ and are very slow below $\mathrm{pH}$ 8.5. Therefore, sulfate and manganese from the tributary streams do not readily precipitate and can have an additive effect on mainstem sulfate and manganese discharges. Muddy Creek (site 54) contributed the largest sulfate discharge of 26 ton/d; Bull Run (site 111) and Lick Run (site 11) contributed 6.7 ton/d and 6.0 ton/d, respectively (fig. 2). The manganese discharge from Muddy Creek (site 54) 

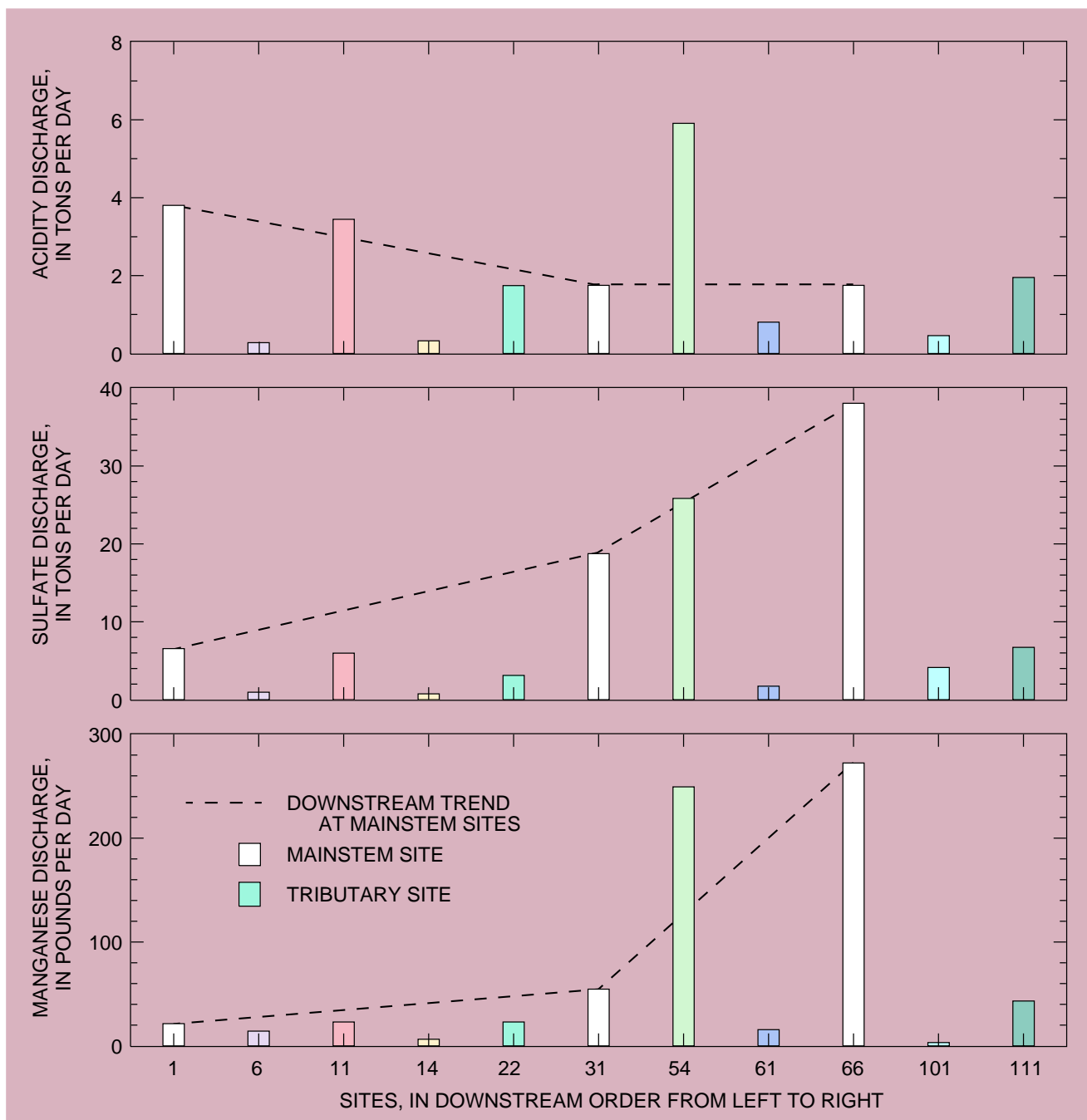

Figure 2. Discharges of total acidity, dissolved sulfate, and total manganese measured in the mainstem and in eight tributary streams in the Lower Cheat River Basin on July 16-18, 1997.

was 249 pounds per day, which was nearly twice the manganese discharge of all the other seven major tributary streams. Muddy Creek was the tributary stream that had the most detrimental affect on the mainstem water quality.

\section{RANKING OF StREAM DEGRADATION}

In order to categorize the severity of AMD at all sampling sites in the Lower Cheat River Basin, a system was developed to rank these sites on the basis of discharges of five selected chemical constituents that are generally associated with coal-mine drainage. A priority numbering system, or prioritization index (PI), developed by Williams and others (1996) to prioritize mine discharges for remediation in the Stonycreek River Basin in southwestern Pennsylvania, was used to prioritize all sampling sites in the Lower Cheat River Basin. The PI can assist water-resources managers in considering remedial actions in the many tributary basins and subbasins throughout the Lower Cheat River Basin. The major difference between the two indexes was that the Stonycreek
River Basin index was applied to point-source mine discharges, whereas the Cheat River Basin index is applied to mainstem river sites, tributary stream sites, and subbasin stream sites within the major tributaries.

The PI for the Lower Cheat River Basin is based on a siteto-site comparison of the discharges of selected chemical constituents-total iron, total manganese, dissolved aluminum, total heated acidity, and dissolved sulfate. Stream $\mathrm{pH}$ was indirectly used in the PI as the "tiebreaker" for constituent discharges that were identical. These factors are related either directly or indirectly to the effects of coal-mine drainage on water quality. Low $\mathrm{pH}$ and high acidities are common to the most severely affected streams. Total iron, total manganese, and $\mathrm{pH}$ in coal-mine discharges are limited by Federal regulations. The sulfate discharge is a reliable indicator of mine drainage because the neutralization processes in streams do not greatly affect sulfate concentrations (Tolar, 1982). Dissolved aluminum in waters having low $\mathrm{pH}$ affects fish and some other forms of aquatic life (Driscoll and others, 1980).

Streamflow is a significant factor in the computation of the PI for a site because the streamflow multiplied by the concentration of a constituent and a constant determines the constituent discharge. The constant is used to convert concentration (in milligrams per liter or micrograms per liter) per flow rate (in cubic feet per second) to either pounds per day or tons per day. The constituent discharge in pounds per day or tons per day divided by the drainage area in square miles gives the yield in pounds per day per square mile or tons per day per square mile.

In order to standardize the PI for the Cheat River Basin sites, constituent discharges per square mile of drainage area (this is known as "yield") were used for the calculations. The yields of each constituent were sorted in order of ascending or improving water quality. For example, the sorted, ranked, and scored total-iron data are listed in table 3 . The left four columns of table 3 show the unsorted total-iron data for sites 1 through 25 . 
The right six columns of table 3 show how the 24 sites with the highest total-iron yields were sorted, ranked, and scored. The text below refers to the sorted total-iron data in table 3. A rank number was assigned to each total-iron yield in a descending order; rank 1 was for the largest total-iron yield $\left(1,980 \mathrm{lb} / \mathrm{d} / \mathrm{mi}^{2}\right.$ (pounds per day per square mile)), and rank 24 was for the smallest total-iron yield $\left(9.7 \mathrm{lb} / \mathrm{d} / \mathrm{mi}^{2}\right)$. Each yield was then given a score on the basis of the rank. A score of 1 to 10 was assigned to each yield by subdividing the 111 sites into 10-percent groups. The first 10-percent group (rank 1-11) received a score of 10 . The next 10-percent group (rank 12-22) received a score of 9 , and so on. The final 10-percent group (rank 100-111) that received a score of 1 contained 12 sites instead of 11 . Yields for all five chemical constituents were sorted, ranked, and scored by this method. The final score for each site was then calculated by adding the scores for the five chemical constituents. For example, the final score and PI for sites 20, 58, 44, and 22 are listed in table 4 . The final rank or PI was determined by assigning the largest final score the number 1, the second largest score the number 2, and so forth through all 111 sites (table 5). Streamflow was used as the first tie breaker for identical final scores. The site with the largest streamflow received the lower rank number. In table 4 , sites 20 and 58 had final scores of 48 , but site 20 had the largest streamflow and was assigned the lower PI number. Larger streamflows can potentially produce greater discharges of the chemical constituents that can be detrimental. Stream $\mathrm{pH}$ was used as the second tiebreaker for sites with identical final scores and identical streamflows. The site with the lowest $\mathrm{pH}$ received the lower rank number. The final PI shows which sites have the greatest potential effect per square mile on the water quality of the receiving streams. Seventy percent of the 20 highest ranked sites are in the Muddy Creek, Greens Run, and Bull Run Basins. The highest ranked sites in table 5 (sites $50,49,48)$ were all in the Muddy Creek Basin. It is apparent the water quality at site 48 (Fickey Run at mouth) is very poor, and the yields for the five chemical constituents were by far greater at this site than at all other 110 sites. However, because streamflow is used as a tiebreaker, site 48 had a PI of 3 . If water-resource managers consider remediation in specific basins on the basis of the final PI, they need to take into consideration all factors used to arrive at the index. It may be advisable to collect additional samples at different flows in order to verify stream water quality with respect to the PI.

Table 4. Individual constituent ranks, scores, final scores, and prioritization index for sites 20, 58, 44, and 22, based on yields

[Yields of total iron, total manganese, and dissolved aluminum are in pounds per day per square mile; yields of dissolved sulfate and total acidity as $\mathrm{CaCO}_{3}$ are in tons per day per square mile; streamflow is in cubic feet per second]

\begin{tabular}{|c|c|c|c|c|c|c|c|c|c|c|c|c|c|c|c|c|c|c|}
\hline $\begin{array}{c}\text { Site } \\
\text { number }\end{array}$ & $\begin{array}{c}\text { Sulfate, } \\
\text { dissolved }\end{array}$ & Rank & Score & $\begin{array}{l}\text { Iron, } \\
\text { total }\end{array}$ & Rank & Score & $\begin{array}{c}\text { Manganese, } \\
\text { total }\end{array}$ & Rank & Score & $\begin{array}{c}\text { Aluminum, } \\
\text { dissolved }\end{array}$ & Rank & Score & $\begin{array}{l}\text { Acidity, total } \\
\text { as } \mathrm{CaCO}_{3}\end{array}$ & Rank & Score & $\begin{array}{l}\text { Stream- } \\
\text { flow }\end{array}$ & $\begin{array}{l}\text { Final } \\
\text { score }\end{array}$ & $\begin{array}{l}\text { Prioritization } \\
\text { index }\end{array}$ \\
\hline 20 & 0.6 & 16 & 9 & 121 & 5 & 10 & 4.2 & 21 & 9 & 59 & 9 & 10 & 0.41 & 7 & 10 & 1.2 & 48 & 9 \\
\hline 58 & .76 & 13 & 9 & 89 & 7 & 10 & 5.8 & 18 & 9 & 48 & 11 & 10 & .36 & 9 & 10 & .64 & 48 & 10 \\
\hline 22 & .48 & 18 & 9 & 58 & 11 & 10 & 3.5 & 26 & 8 & 40 & 12 & 9 & .27 & 11 & 10 & 1.7 & 46 & 12 \\
\hline
\end{tabular}


Table 5. Prioritization index (PI) for the 111 sampled sites in the Lower Cheat River Basin, based on yields

[Yields of total iron, total manganese, and dissolved aluminum are in pounds per day per square mile; yields of dissolved sulfate and total acidity as $\mathrm{CaCO}_{3}$ are in tons per day per square mile; streamflow is in cubic feet per second; <, less than]

\begin{tabular}{|c|c|c|c|c|c|c|c|c|c|c|c|c|c|c|c|c|c|c|c|}
\hline $\begin{array}{c}\text { Site } \\
\text { number }\end{array}$ & Streamflow & $\mathrm{pH}$ & $\begin{array}{l}\text { Sulfate, } \\
\text { dissolved }\end{array}$ & $\begin{array}{l}\text { Iron, } \\
\text { total }\end{array}$ & $\begin{array}{l}\text { Manganese, } \\
\text { total }\end{array}$ & $\begin{array}{l}\text { Aluminum, } \\
\text { dissolved }\end{array}$ & $\begin{array}{l}\text { Acidity, } \\
\text { total as } \\
\mathrm{CaCO}_{3}\end{array}$ & $\begin{array}{l}\text { Final } \\
\text { score }\end{array}$ & PI & $\begin{array}{c}\text { Site } \\
\text { number }\end{array}$ & Streamflow & $\mathrm{pH}$ & $\begin{array}{l}\text { Sulfate, } \\
\text { dissolved }\end{array}$ & $\begin{array}{l}\text { Iron, } \\
\text { total }\end{array}$ & $\begin{array}{l}\text { Manganese, } \\
\text { total }\end{array}$ & $\begin{array}{l}\text { Aluminum, } \\
\text { dissolved }\end{array}$ & $\begin{array}{l}\text { Acidity, } \\
\text { total as } \\
\mathrm{CaCO}_{3}\end{array}$ & $\begin{array}{l}\text { Final } \\
\text { score }\end{array}$ & $\mathrm{PI}$ \\
\hline 50 & 11 & 3.2 & 1.13 & 93 & 18 & 63 & 0.37 & 50 & 1 & $21 \mathrm{~A}$ & 0.12 & 7.1 & 0.05 & 0.10 & 0.60 & 0.01 & $<0.01$ & 25 & 57 \\
\hline 49 & 3.3 & 2.9 & 1.78 & 152 & 28 & 100 & .59 & 50 & 2 & 42 & 3.5 & 7.4 & .07 & .14 & .07 & .05 & $<.01$ & 24 & 58 \\
\hline 48 & 1.2 & 2.7 & 5.29 & 1,980 & 66 & 368 & 3.0 & 50 & 3 & 88 & 1.6 & 6.4 & .03 & .10 & .73 & .02 & $<.01$ & 24 & 59 \\
\hline 57 & .69 & 2.7 & 2.48 & 517 & 21 & 178 & 1.6 & 50 & 4 & 23 & .64 & 6.3 & .11 & .01 & .53 & .03 & $<.01$ & 23 & 60 \\
\hline 106 & 2.2 & 3.1 & 2.49 & 83 & 8.4 & 137 & .74 & 49 & 5 & 94 & 6.3 & 7.3 & .05 & .05 & .15 & .03 & $<.01$ & 22 & 61 \\
\hline 46 & 1.8 & 3.2 & 1.56 & 12 & 36 & 83 & .32 & 49 & 6 & 38 & 1.7 & 7.1 & .01 & .18 & .03 & .06 & $<.01$ & 22 & 62 \\
\hline${ }^{1} 11$ & 1.7 & 2.6 & 1.22 & 357 & 4.7 & 104 & .70 & 49 & 7 & 89 & 1.6 & 6.4 & .03 & .08 & .51 & .01 & $<.01$ & 22 & 63 \\
\hline 12 & .31 & 2.7 & .96 & 66 & 8.4 & 65 & .49 & 49 & 8 & 37 & .70 & 7.6 & $<.01$ & .29 & .04 & .03 & $<.01$ & 22 & 64 \\
\hline 20 & 1.2 & 2.6 & .60 & 121 & 4.2 & 59 & .41 & 48 & 9 & 78 & .59 & 6.3 & .01 & .29 & .25 & .01 & $<.01$ & 22 & 65 \\
\hline 58 & .64 & 2.8 & .76 & 89 & 5.8 & 48 & .36 & 48 & 10 & 39 & .12 & 4.8 & $<.01$ & .34 & .19 & .14 & $<.01$ & 22 & 66 \\
\hline 44 & .19 & 3.3 & 1.20 & 9.7 & 46 & 57 & .22 & 47 & 11 & ${ }^{2} 66$ & 174 & 6.2 & .03 & .03 & .24 & .04 & $<.01$ & 21 & 67 \\
\hline${ }^{1} 22$ & 1.7 & 2.8 & .48 & 58 & 3.5 & 40 & .27 & 46 & 12 & ${ }^{2} 31$ & 125 & 7.0 & .01 & .07 & .04 & .09 & $<.01$ & 21 & 68 \\
\hline${ }^{1} 54$ & 11 & 3.2 & .76 & 30 & 7.4 & 27 & .17 & 45 & 13 & 85 & 2.3 & 6.7 & .02 & .22 & .24 & $<.01$ & $<.01$ & 21 & 69 \\
\hline 98 & .34 & 3.3 & .48 & 6.9 & 9.5 & 39 & .17 & 45 & 14 & 86 & .13 & 6.3 & .01 & .21 & .64 & $<.01$ & $<.01$ & 21 & 70 \\
\hline 45 & .08 & 3.1 & .71 & 4.8 & 22 & 35 & .14 & 45 & 15 & 53 & .05 & 6.4 & .04 & 2.0 & .19 & $<.01$ & $<.01$ & 21 & 71 \\
\hline 17 & .07 & 2.7 & .40 & 26 & 9.0 & 37 & .24 & 45 & 16 & 36 & 2.8 & 7.3 & .04 & .04 & .01 & .03 & $<.01$ & 20 & 72 \\
\hline 43 & .77 & 4.4 & 1.91 & 26 & 26 & 2.9 & .07 & 44 & 17 & 84 & .23 & 7.0 & .02 & .32 & .08 & .01 & $<.01$ & 20 & 73 \\
\hline 59 & .23 & 2.6 & .42 & 59 & 3.9 & 28 & .23 & 44 & 18 & 114 & .16 & 5.2 & $<.01$ & .11 & .07 & .16 & $<.01$ & 20 & 74 \\
\hline${ }^{1} 111$ & 4.7 & 3.2 & .61 & 7.8 & 3.9 & 34 & .18 & 43 & 19 & 80 & .08 & 6.8 & .01 & .67 & .23 & $<.01$ & $<.01$ & 20 & 75 \\
\hline 108 & 2.7 & 3.2 & .45 & 8.9 & 2.8 & 25 & .13 & 43 & 20 & 77 & .06 & 6.1 & $<.01$ & .68 & .06 & .04 & $<.01$ & 20 & 76 \\
\hline${ }^{1} 14$ & .65 & 3.0 & .34 & 11 & 2.9 & 23 & .15 & 43 & 21 & 21 & 128 & 7.7 & .01 & .05 & .02 & .03 & $<.01$ & 19 & 77 \\
\hline 19 & .45 & 2.6 & .32 & 51 & 2.9 & 33 & .22 & 43 & 22 & 34 & .21 & 6.6 & $<.01$ & .36 & .07 & .01 & $<.01$ & 19 & 78 \\
\hline 112 & .29 & 3.8 & 1.23 & 2.7 & 31 & 13 & .09 & 43 & 23 & 81 & .14 & 6.6 & .02 & .15 & .08 & .01 & $<.01$ & 19 & 79 \\
\hline 60 & .65 & 2.7 & .29 & 31 & 2.3 & 19 & .22 & 42 & 24 & 32 & .73 & 7.8 & $<.01$ & .08 & .02 & .04 & $<.01$ & 18 & 80 \\
\hline 99 & .63 & 3.5 & .28 & 1.8 & 5.9 & 26 & .10 & 41 & 25 & 82 & .41 & 6.5 & .02 & .07 & .12 & .01 & $<.01$ & 18 & 81 \\
\hline 102 & .27 & 3.6 & .42 & .59 & 7.0 & 22 & .09 & 41 & 26 & ${ }^{1} 101$ & 18 & 7.1 & .02 & .01 & .02 & .03 & $<.01$ & 17 & 82 \\
\hline 104 & .15 & 3.0 & .29 & 4.0 & 7.6 & 20 & .10 & 41 & 27 & 8 & .16 & 7.9 & .05 & .04 & .02 & .01 & $<.01$ & 17 & 83 \\
\hline${ }^{1} 61$ & .90 & 2.8 & .19 & 18 & 1.7 & 13 & .09 & 40 & 28 & 83 & .12 & 7.3 & .03 & .06 & .03 & .01 & $<.01$ & 17 & 84 \\
\hline 18 & .08 & 2.9 & .18 & 4.6 & 5.4 & 18 & .09 & 40 & 29 & 71 & 5.6 & 6.1 & $<.01$ & .13 & .06 & $<.01$ & $<.01$ & 16 & 85 \\
\hline 10 & .20 & 2.9 & .15 & 19 & .97 & 12 & .09 & 39 & 30 & 67 & 4.2 & 6.2 & $<.01$ & .12 & .05 & .01 & $<.01$ & 16 & 86 \\
\hline 109 & .16 & 3.2 & .22 & 2.4 & 2.1 & 11 & .06 & 39 & 31 & 27 & .05 & 7.2 & $<.01$ & .95 & .04 & $<.01$ & $<.01$ & 16 & 87 \\
\hline 4 & .96 & 3.4 & .14 & 3.7 & 2.0 & 12 & .06 & 38 & 32 & 30 & 1.1 & 7.5 & .02 & .05 & .01 & .01 & $<.01$ & 15 & 88 \\
\hline 3 & .24 & 3.1 & .18 & 9.8 & 1.7 & 17 & .10 & 38 & 33 & 25 & .10 & 7.1 & .06 & .02 & .03 & $<.01$ & $<.01$ & 15 & 89 \\
\hline 16 & .12 & 3.3 & .10 & 3.4 & 2.4 & 11 & .05 & 38 & 34 & 76 & .03 & 6.9 & .01 & .18 & .05 & $<.01$ & $<.01$ & 15 & 90 \\
\hline 15 & .17 & 2.9 & .12 & 10 & 1.7 & 5.7 & .05 & 37 & 35 & 90 & 4.3 & 6.2 & .03 & .04 & .03 & $<.01$ & $<.01$ & 14 & 91 \\
\hline 24 & 1.1 & 4.5 & .42 & .20 & 3.9 & 2.3 & .02 & 36 & 36 & 74 & .15 & 7.0 & $<.01$ & .17 & .02 & $<.01$ & $<.01$ & 14 & 92 \\
\hline${ }^{1} 6$ & .97 & 3.4 & .10 & .52 & 1.4 & 6.1 & .03 & 34 & 37 & 29 & .15 & 7.2 & $<.01$ & .07 & .01 & $<.01$ & $<.01$ & 14 & 93 \\
\hline 105 & .39 & 3.4 & .11 & .17 & 2.2 & 5.4 & .02 & 34 & 38 & 55 & .03 & 4.0 & $<.01$ & $<.01$ & .04 & .05 & $<.01$ & 12 & 94 \\
\hline 9 & .25 & 3.1 & .06 & 2.1 & 1.2 & 4.3 & .03 & 34 & 39 & 47 & .01 & 7.1 & $<.01$ & .14 & .03 & $<.01$ & $<.01$ & 12 & 95 \\
\hline 70 & .72 & 6.6 & .08 & .11 & .03 & .01 & $<.01$ & 33 & 40 & 68 & .87 & 5.9 & $<.01$ & .10 & .02 & $<.01$ & $<.01$ & 10 & 96 \\
\hline 2 & .20 & 3.2 & .05 & 1.5 & .65 & 3.3 & .02 & 33 & 41 & 28 & .46 & 7.3 & $<.01$ & .02 & $<.01$ & $<.01$ & $<.01$ & 10 & 97 \\
\hline 64 & .04 & 3.2 & .12 & 3.6 & 4.0 & 8.2 & $<.01$ & 33 & 42 & 96 & .23 & 6.7 & .01 & .01 & .01 & $<.01$ & $<.01$ & 10 & 98 \\
\hline 107 & .09 & 3.3 & .05 & .23 & .39 & 4.3 & .02 & 31 & 43 & 62 & .02 & 7.0 & $<.01$ & $<.01$ & $<.01$ & $<.01$ & $<.01$ & 10 & 99 \\
\hline 91 & .53 & 7.3 & .22 & .32 & .13 & .04 & .02 & 30 & 44 & 26 & .03 & 7.3 & $<.01$ & $<.01$ & $<.01$ & $<.01$ & $<.01$ & 9 & 100 \\
\hline 51 & .75 & 8.0 & .22 & .39 & .19 & .03 & $<.01$ & 29 & 45 & 65 & .02 & 6.8 & $<.01$ & .09 & .01 & $<.01$ & $<.01$ & 9 & 101 \\
\hline 92 & .10 & 4.6 & .09 & .06 & 1.8 & 2.5 & .01 & 29 & 46 & 35 & .02 & 8.0 & $<.01$ & .10 & .01 & $<.01$ & $<.01$ & 9 & 102 \\
\hline 7 & .06 & 3.8 & .03 & .19 & 1.9 & 1.7 & .01 & 29 & 47 & 52 & .01 & 6.9 & $<.01$ & .02 & .01 & $<.01$ & $<.01$ & 9 & 103 \\
\hline 87 & .52 & 5.1 & .01 & .72 & .37 & .24 & $<.01$ & 28 & 48 & 21 & .05 & 7.7 & $<.01$ & .03 & .01 & $<.01$ & $<.01$ & 8 & 104 \\
\hline 33 & .76 & 4.5 & .01 & .17 & .38 & .96 & .01 & 27 & 49 & 113 & .01 & 6.5 & $<.01$ & .06 & .02 & $<.01$ & $<.01$ & 8 & 105 \\
\hline 100 & .23 & 4.0 & .03 & .05 & .86 & 2.9 & .01 & 27 & 50 & 63 & .01 & 6.7 & $<.01$ & .06 & .03 & $<.01$ & $<.01$ & 8 & 106 \\
\hline 110 & .08 & 4.0 & .04 & .05 & .42 & 1.6 & .01 & 27 & 51 & 103 & .03 & 7.2 & $<.01$ & $<.01$ & $<.01$ & $<.01$ & $<.01$ & 7 & 107 \\
\hline 56 & .03 & 4.0 & .02 & 15 & .38 & $<.01$ & .01 & 27 & 52 & 97 & .51 & 7.4 & $<.01$ & .01 & $<.01$ & $<.01$ & $<.01$ & 6 & 108 \\
\hline 41 & 2.8 & 6.1 & .04 & .23 & .51 & .05 & $<.01$ & 26 & 53 & 95 & .20 & 6.9 & $<.01$ & .01 & .01 & $<.01$ & $<.01$ & 6 & 109 \\
\hline 40 & 2.2 & 7.7 & .02 & .30 & .07 & .30 & .01 & 26 & 54 & 69 & .03 & 6.4 & $<.01$ & $<.01$ & $<.01$ & $<.01$ & $<.01$ & 5 & 110 \\
\hline 93 & .52 & 7.3 & .15 & .05 & .90 & .03 & $<.01$ & 25 & 55 & 72 & .01 & 7.2 & $<.01$ & .02 & $<.01$ & $<.01$ & $<.01$ & 5 & 111 \\
\hline 79 & .51 & 6.3 & $<.01$ & .26 & .27 & .03 & .01 & 25 & 56 & & & & & & & & & & \\
\hline
\end{tabular}

${ }_{2}^{1}$ Site is at the mouth of a major tributary.

2 Site is on the mainstem. 


\section{MAJOR FINDINGS}

Water-quality data from the three mainstem sites on the Cheat River indicated a progressive degradation in water quality from site 1 to outflow site 66 . Specific conductance increased from 110 to $220 \mu \mathrm{S} / \mathrm{cm}, \mathrm{pH}$ decreased from 7.7 to 6.2 , alkalinity decreased from 26 to $4.5 \mathrm{mg} / \mathrm{L}$, sulfate concentrations increased from 19 to $81 \mathrm{mg} / \mathrm{L}$, and manganese concentrations increased from 31 to $290 \mu \mathrm{g} / \mathrm{L}$.

The quality of water in seven major tributary streams in the Lower Cheat River Basin was severely affected by AMD, and those tributaries had a significant effect on the mainstem water quality. In those seven tributary streams, specific conductance ranged from 827 to $2,180 \mu \mathrm{S} / \mathrm{cm}$, pH values were all less than 3.5, acidities ranged from 105 to $750 \mathrm{mg} / \mathrm{L}$, sulfate concentrations ranged from 370 to $1,300 \mathrm{mg} / \mathrm{L}$, and concentrations of iron, manganese, and aluminum were all very high.

Muddy Creek, which has the largest drainage area (33.8 square miles) of the seven tributary streams severely affected by AMD, had the most detrimental effect on the mainstem water quality.

The prioritization index developed to assist water-resource managers in considering remediation possibilities in many tributary basins and subbasins throughout the Lower Cheat River Basin shows that 70 percent of the 20 highest ranked sites are in the Muddy Creek, Greens Run, and Bull Run Basins and that the 3 highest ranked sites were all in the Muddy Creek Basin.

\section{ReferenCes Cited}

Coll, M.B., Jr., and Siwicki, R.W., 1997, Water resources data for Pennsylvania, v. 3, Ohio River and St. Lawrence River Basins: U.S. Geological Survey Water-Data Report PA-97-3, 339 p.

Driscoll, C.T., Baker, J.P., Bisogni, J.J., Jr., and Schofield, C.L., 1980, Effect of aluminum speciation on fish in dilute acidified water: Nature, v. 284, p. 161-164.

Fenneman, N.M., 1946, Physical divisions of the United States: Washington, D.C., U.S. Geological Survey special map, scale 1:7,000,000.

Tolar, L.G., 1982, Some chemical characteristics of mine drainage in Illinois: U.S. Geological Survey Water-Supply Paper 1078, $47 \mathrm{p}$.

U.S. Office of Surface Mining, 1998, Abandoned mine land inventory system (AMLIS), accessed May 15, 1998, at URL http://www.osmre.gov/zamlis.html.

West Virginia Department of Environmental Protection, February, 1996, National Pollution Discharge Elimination System (NPDES) database.

Williams, D.R., Sams III, J.I., Mulkerrin, M.E., 1996, Effects of coal-mine discharges on the quality of the Stonycreek River and its tributaries, Somerset and Cambria Counties, Pennsylvania: U.S. Geological Survey Water-Resources Investigations Report 96-4133, 95 p.

\section{FOR MORE INFORMATION}

Information about the NAWQA Program can be obtained from:

NAWQA Project Chief U.S. Geological Survey 1000 Church Hill Road

Pittsburgh, PA 15205

Phone: 412.490 .3800

Fax: 412.490 .3828

For information on USGS programs and activities in Pennsylvania,

please visit our web site at

http://pa.water.usgs.gov

or contact

District Chief USGS, WRD

840 Market Street Lemoyne, PA 17043-1584

Phone: 717.730 .6900

Fax: 717.730 .6997 email: dc_pa@usgs.gov

Additional earth science information can be found by accessing the USGS Home Page at

http://www.usgs.gov

For information on all USGS products and services, call 1.800.ASK.USGS

Fax: 703.648 .5548 email: esic@usgs.gov 